\title{
Determinants Impacting Consumers' Purchase Intention: The Case of Fast Food in Vietnam
}

\author{
The Anh Phan ${ }^{1} \&$ Phuong Hoang Mai ${ }^{1}$ \\ ${ }^{1}$ Eastern International University, Binh Duong, Vietnam \\ Correspondence: The Anh Phan, Eastern International University, Binh Duong, Vietnam. E-mail: \\ anh.phanthe@eiu.edu.vn
}

Received: July 6, 2016 Accepted: August 29, 2016 Online Published: September 22, 2016

doi:10.5539/ijms.v8n5p56 URL: http://dx.doi.org/10.5539/ijms.v8n5p56

\begin{abstract}
The purpose of this case study is to explore and study the determinants impacting Vietnamese students' food choice and the pattern of consumption of fast food in university students. The objective set for this research was conduct with the following objectives respectively getting an insight of fast food market in Vietnam and explore the attributes that Vietnamese students in perceive to be important in the selection of fast food restaurants and the study results provide a better understanding about the industry and consumer food choice variables The model and the design of the questionnaire content in this study was based on the measures of previous related research and literatures and several constructs were measured by single item scale, E-S-QUAL scale (Parasuraman et al., 2005) that has been developed and used in the present study has been shown to be a valid instrument for the measurement with four main factors (Health Consciousness, Value Perceived, Food Safety and Price) toward with Purchase Intention. In this regard, other questions were also applied in the survey to get an insight about demographic information and consumption habits of students in this research. Moreover, we found significant positive relationship between the purchase intentions and food safety, subsequently price and value perceived with similar positive relationships. Hence we can say that managers have to keep these factors in mind to perform better.
\end{abstract}

Keywords: students' purchase intention, health consciousness, perceived value, food safety, price, fast food, Vietnam

\section{Introduction}

Nowadays, the food corporates have been grown in interest and adoption successfully in replacing healthy food and fresh from consumers' diet with processed food. Fast food consumption spread out rapidly as the basic needs. Several studies have been devoted to understand the factors that encourage or discourage the adoption of acceptance of fast food but little research exits on fast food and health consciousness in purchase intentions, e.g. for woman, the gain in the mass weight is found to be directly proportional to the fast food (Jeffery \& French, 1998). In social context, due to global change the working styles of people, they have less time to cook at home and they spend more money on fast food. Understanding the needs, there has been a gradual demand for the fast food and has become one of the fastest growing industries, the corporates continuously created new campaigns for their brand to make their products becoming closer and more convenient to customers.

The fast food industry accelerated at a great pace and become the large chains of the food industry (Lattin, 1985). The growing competitive pressure from other industries poses serious challenges for traditional fast food chains with the big foreign brands like KFC, Lotteria and Jollibee from 2004, and it is more fierce with the big brother of America's top brands, McDonald's. The good example is that Kentuchy Fried Chicken (KFC) represents the population of interest, 44 fast-food outlets in Vietnam, and estimated to reach 100 stores in 3 years (Thịtrườngfastfood, n.d.). According to statistics of the Ministry of Industry and Trade, the total sales of the fast food industry in $\mathrm{VN}$ in 2011 is estimated at 870 billion, up 30\% from 2010. With growth of 30\% per year, fast food market is the potential industry which has a high growth and stability in the consumption food industry recently (Phuong, 2013).

\subsection{Explore Importance of the Problem}

Fast food industry is a high growing sector; fast food segment has been changing very fast over last decade. 
Because of time constrains which easily found in young adults such as students and people with higher income (Pereira et al., 2005). Students are highly exposed to unhealthy eating habits leading to body weight gain (Huang et al., 2003). This customer segment is very potential in the field of fast food business; the growth of fast food industry has been an important environment inducement for increases food consumption (Block et al., 2004). Furthermore, it also satisfies the dietary needs and entertainment of young people. Fast food is gaining acceptance primarily from students and younger generation and is becoming part of life. It gradually affects their daily habits of eating and becomes their lifestyle with bad dietary habits. In addition, actual situation of food safety and hygiene nowadays is alarming. It is necessary to have food stores that ensure safe and hygienic food. From those opportunities, it is worth to do a business in this potential market, and starting a business with fast food industry, students are the potential segments in this business; therefore this study was conducted to investigate "determinants impacting students' purchase intentions".

\subsection{Literature Review}

\subsubsection{Purchase Intention}

Paul \& Fred (1985), purchase intention is defined as a plan to purchase certain good or service in the future. In another view, purchase intention could be useful by understand the possibility of a customer on that lead to a purchasing action, purchase intention is to measure the possibility of buying certain product by the consumer (Schiffman \& Kanuk, 2004), the higher possibility to purchase particular product or service occur (Schiffman \& Kanuk, 2000). Purchase intention can be described as a key indicator to predict consumption behavior (Keller, 2001). Through a process of consumer behavior toward buying a product or a service, the consumer's purchase intention might be formed by recognition, information seeking, alternative products evaluating, purchasing behavior and post-purchase step of mind (Schiffman \& Kanuk, 2000).

\subsubsection{Health Consciousness}

Health consciousness assesses the readiness to undertake health actions (Becker, Kirscht, Haefner, \& Drachman, 1977). The consumers are aware and concerned about their wellness and are motivated to improve, maintain their health and quality of life to prevent ill health by engaging in healthy behaviors and being self-conscious regarding health (Newsom, McFarland, Kaplan, Huguet, \& Zani, 2005). Moreover, almost individuals tend to be aware of the issues related to nutrition and physical fitness (Kraft \& Goodell, 1993). In addition, health consciousness has been found to predict purchase intention of food affecting consumers' health. Relationship between health consciousness and purchase intention: according to Davies et al. (1995), since consumers' perception whether food is healthy for them or not, it is one the most frequent motivations to purchase. Grankvist \& Biel (2001) have identified interest in health as a primary motive for the purchase of food products. Particularly, health consciousness has been found to predict attitudes, intention and purchase of food. As a result, in order to make better purchase intention of food the matter of increased health care through proper nutrition seems as a key factor (Grankvist \& Biel, 2001).

H1: Health consciousness exercises a positive impact on purchase intention.

\subsubsection{Value Perceived}

Value is the gap between consumer perceived benefits and perceived costs (Day, 1990; Leszinski \& Mam, 1997). Perceived value has been viewed as what consumers get for what they give, or the consumer's overall evaluation of the utility of a product or service provision based on perceptions of what one receives for what one gives (Julie \& Dhruv, 1994). In addition, Zeithaml (1988) identified four common uses of the term of value respectively the low price customer get, whatever customer wan in a product, the quality customer get for the price they pay and what customer get for what they give (Zeithaml, 1988).

Relationship between perceived value and purchase intention: Dodds \& Monroe (1985) mentioned that perceived value is an important factor in consumers' purchasing decision process, and consumers will buy a product with high perceived value. Dodds \& Monroe (1985) and Zeithaml (1988) contended that consumers will evaluate what they give and what they get in their subjective perception when they are buying a product or service. According to Utility Theory, the probability of purchase intention will increase, when consumers acquire more benefits than they pay for a product (Peter \& Alan, 1990). Yet it can be argued that perceived value is an important antecedent to influence consumer purchase intention because it is the composition of transaction utility and acquisition utility (Thaler, 1985).

H2: Perceived value exercises a positive impact on purchase intention. 


\subsubsection{Food Safety}

Food safety refers to the conditions and practices that preserve the quality of food to prevent contamination and foodborne illnesses. In reality, food can be contaminated in a variety of ways. E.g. food products may already contain bacteria and parasites or these germs can be spread during the packaging process if the food products are not handled properly. Further food contamination causes are associated with improperly cooking or storing (Vorvick, 2014). Food buyers are equally concerned about the physical risks involved in the consumption of foods (Wallace, Ruth, \& Joe, 2005). It is more likely that food safety represents consumers' concern of residues in food resulting from chemical sprays, fertilizers, artificial additives and preservatives and is often linked to farming methods (Wallace, Ruth, \& Joe, 2005).

There is a relationship between food safety and purchase intention: customers are willing to pay for a value attached to the improvements of food safety, food safety is a basement before making buying decision from customers (Henson, 1996). The author also explained the factors that affect willingness to pay for reductions in the risk of food poisoning are personal experiences of food poisoning, consumers' attitudes towards food poisoning, perceived control over the risk of food poisoning and the individual customer characteristic itself (Henson, 1996). Food safety thus can be positive indicator as a motivation for purchasing food products and its relationship with attitudes and intention towards foods is yet to be formally modeled (Padel \& Foster, 2005).

H3: Food safety exercises a positive impact on purchase intention.

\subsubsection{Price}

Price is always the most concerned issue from the consumers whenever they make a buying decision (Smith \& Carsky, 1996). Meanwhile, Nagle \& Holden (2002) indicated the role of price as a monetary value, using by the consumers in order to trade with the sellers for the products or services (Nagle \& Holden, 2002).

In details, consumers have a tension to separate the higher price with higher quality and conversely the lower price with inferior quality, as almost consumers' perception are aware of the high-priced goods and services are equal to high quality (Etgar \& Malhotra, 1981). Therefore, if the quality of products and services comply with the consumers' expectation, they should accept a price level at peak to fulfill their demand. The consumers might consider the price at a fair deal and willing to pay at a higher price if they could be deserved with the quality of products or services (Monroe, 2003).

There is a relationship between price and purchase intentions: price is an obstacle to consumer purchase for food products due to high price will lower consumers' capacity of purchasing for the product, especially low income consumers, and it makes consumers perceive the impossibility to purchase food products, makes them feel uneasy or difficult in performing their purchase decision for the product (Anssi \& Sanna, 2005). Moreover, it can be seen that price as one of the elements of perceived behavioral control for its ability to limit the purchases of consumers, some researchers also say that numerous consumers place their purchases mainly base on price (Zeinab \& Seyedeh, 2012). Therefore, we can assume that price highly impacts on consumer purchase intention for a food product.

H4: Price exercises a positive impact on purchase intention.

\subsection{State Hypotheses and Their Correspondence to Research Design}

Based on the research model of MohdRizaimyShaharudin; Jacqueline JunikaPani; Suhardi Wan Mansor and ShasulJamel Elias/ Cross-cultural Communication Vol.6 No.2 2010, the conceptualization framework of the research model is shown in Figure 1, on the basis of the above literature reviews, the following hypotheses are proposed for the present study:

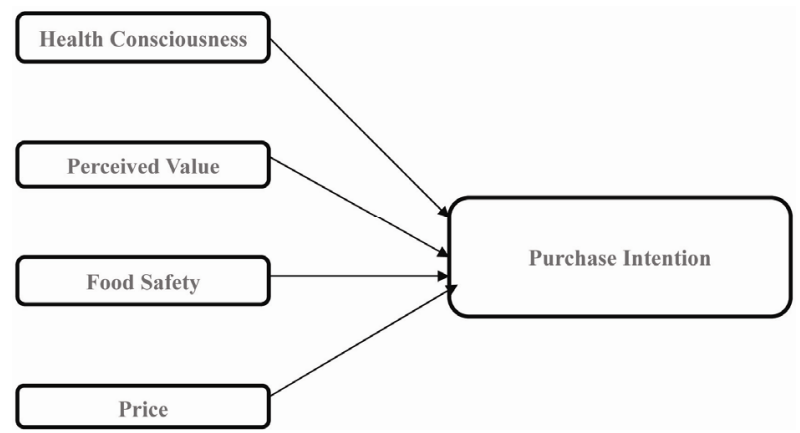

Figure 1. The conceptual framework 


\section{Methodology}

Initially, this study started with the research question and then finding out the research objectives simultaneously. Literature review was built by the academic consultation from the illustrious scholars in the same field regarding with this study. After constituting the research model, then we conducted the qualitative research through the focus group to get the primary data combined with the secondary data collecting by the Internet that lead a design of questionnaires. Subsequently, quantitative research was conducted and then moving on the data collection and analysis section. Finally, the result was given and suggesting the recommendations in conclusion part.

\subsection{Identify Subsections}

The mixed methods research is a way of collecting of analyzing and mixing quantitative in a single study or series of studies Creswell (1999). In the term of subsections, this study started with the qualitative research was designed for the interview of a focus group including 10 students who live and study in central Binh Duong province. It was performed to get the qualitative information concerned with their habit of buying fast food, subsequently identifying and building measurement scale for 4 factors impacting on purchase intention of fast food: health consciousness, value perceived, food safety and price. There were 5 main questions are delivered to the interviewees as following questions: (1) How is your feeling as going to eat fast food?, (2) What do you think if you consume fast food excessively?, (3) How do you feel about the status of fast food safety nowadays?, (4) How do you think about the price of fast food restaurants in Vietnam market? And (5) how often do you purchase fast food?

\subsection{Participant (Subject) Characteristics}

Quantitative research explained phenomena by collecting numeric data and using mathematically based on methods to analyze that. The main purpose of a research was explaining phenomenon which is the significant element of all researches. Particularly, it was conducted to describe dependent and independent variables as well as examining the relationships among them. From that point, finding out what factors affect student's purchase intention of fast food and creating an equation to explain affections.

The participant was selected for this survey was the university students with aged from 18 to 23 years in Binh Duong, Vietnam. The opinions of respondents were collected and combined with the research model to set up the questionnaire that its structure was divided into two main parts: the first part including personal and screening questions: getting the respondents' demographic information about region, gender, income and height and weight and the questions were related to the respondents' purchase habit of fast food like frequency of buying fast food, what restaurants, what time or go with whom. Main questions: including 21 questions about four hypotheses impacting on purchase intention of fast food.

\subsection{Sampling Procedures}

Quota sampling method was conducted for this research with convenient sampling technique to ensure selection of adequate numbers of respondent with characteristics. Because it was quite tough to approach all the list of student's population for probability method, the non-probability quota sampling method would be the best way to collect data. Thus, the survey papers would be sent to 100 students at four universities in Binh Duong province respectively Eastern International University (EIU) with 25 students, Binh Duong University (BDU) with 25 students, Thu Dau Mot University (TDMU) with 25 students and Binh Duong University of Economics and Technique (ETBDU) with 25 students. Sample sizes for each of these universities were based up convenience sampling A summary of the demographic characteristics of the respondents in the study shows no gender bias was detected.

\subsection{Measures and Covariates}

Measurement scale: according to Rensis Likert, this study applied Likert scale which is the most popular in approaching to measure scale responses in survey research. It was conducted to measure the agree level of respondents to the questions about health consciousness, value perceived, food safety, price, and purchase intention with the 5-point Likert scale. All items were assessed on a five-point Likert-type scale (1 - "strongly disagree" to 5 - "strongly agree").

Table 1. The 5-point Likert scale

\begin{tabular}{lllll}
\hline$(1)$ & $(2)$ & $(3)$ & $(4)$ & $(5)$ \\
\hline Strongly disagree & Disagree & Neutral & Agree & Strongly agree \\
\hline
\end{tabular}


Coding: the measurement statements of variables about health consciousness, value perceived, food safety, price and purchase intention are coded as follow:

Table 2. The coded measurement statements

\begin{tabular}{lll}
\hline VARIABLES & CODE & DESCRIPTION \\
\hline Health Consciousness & HC1 & I consider carefully health status when coming to fast food. \\
(HC) & HC2 & I am aware of eating fast food excessively that would be harmful to health. \\
& HC3 & I am bias in the kind of fast food containing less fat and more vegetables. \\
& HC4 & I think fast food provides enough energy like main dishes do. \\
\hline Value Perceived & VP1 & I will only buy fast food on price reduction. \\
(VP) & VP2 & I prefer to purchase fast food because it saves me time. \\
& VP3 & I prefer to purchase fast food because it offers good and fast customer service. \\
& VP4 & I prefer to purchase fast food because it tastes better than home-cooked food. \\
& VP5 & I prefer to purchase fast food because I believe I get good value of money with what I give. \\
\hline Food Safety & FS1 & I concern the quality and safety of fast food nowadays. \\
(FS) & FS2 & I think fast food is totally safe because it has been fried and processed effectively. \\
& FS3 & I am very concerned about the amount of artificial additives and ingredients in processing of fast food. \\
& FS4 & I believed the quality of meat and vegetables are used in fast food restaurants are good. \\
\hline Price & P1 & I think price is my first consideration when I am going to buy fast food. \\
(P) & P2 & I think price of fast food is affordable nowadays. \\
& P3 & I compare prices of many fast food restaurants before buying. \\
& P4 & I think the cheap price may lead to low quality of food and risks. \\
\hline Purchase Intention & PI1 & I will continue buying fast food. \\
(PI) & PI2 & I will buy fast food at least once a week. \\
& PI3 & I intend to increase the frequency of purchasing for fast food. \\
& PI4 & I am willing to recommend my family and friends to purchase fast food.
\end{tabular}

Data was analyzed by using Statistical Package for the Social Science (SPSS) software version 20.0. The section would present an overall view of various techniques to be used in the research for data analysis such as Descriptive Statistics, Reliability Test, Exploratory Factors Analysis, Correlation Test and Multiple Linear Regression Analysis.

\section{Results}

\subsection{Recruitment}

After the content and research framework were established in the early February 2016, the interview of a focus group for the quantitative research was conducted in 7th February 2016. We combined the results from this interview with the secondary data from the Internet to create the questionnaires, then carrying out the survey to university students and collecting data in 14th February. Finally, we completed the rest of research like data analysis, result analysis, discussion and recommendation, format and others till up 14th March.

\subsection{Statistics and Data Analysis}

From Descriptive Statistics: it illustrates each independent variables and dependent variable with the detailed maximum and minimum indicators, and particularly the mean ratio shows how level of agreement among the evaluation of respondents.

According to Reliability Test, all of the items belong to 5 groups Health Consciousness, Value Perceived, Food Safety, Price and Purchase Intention which have Cronbach's Alpha and Corrected Item-Total Correlation satisfy the Reliability test's requirements are greater than 0.6 and 0.3 respectively. Therefore, we retained 21 items at the beginning after this test.

Exploratory Factors Analysis (EFA) was conduct later, after deleting HC4 due to it doesn't satisfy with EFA test's requirements, grouping 16 retained dependent variables again and revising the model research again.

To ensure conditions for hypothesis testing, these variables was tested with Correlation first. On the result, the dependent variable Purchase Intention (PI) is correlated with all independent variables Value Perceived (VP), Price (P), Health Consciousness (HC) and Food Safety (FS) with positive relationship. Food Safety has the strongest relationship with Purchase Intention while Health Consciousness has the weakest one. 
Table 3. Correlations

\begin{tabular}{lllllll}
\hline \multicolumn{2}{l}{ Correlations } & & & & & \\
& & VP & P & HC & FS & PI \\
\hline \multirow{2}{*}{ VP } & Pearson Correlation & 1 & $.506^{* *}$ & $.510^{* *}$ & $.550^{* *}$ & $.576^{* *}$ \\
& Sig. (2-tailed) & & .000 & .000 & .000 & .000 \\
& $\mathrm{~N}$ & 100 & 100 & 100 & 100 & 100 \\
& Pearson Correlation & $.506^{* *}$ & 1 & $.557^{* *}$ & $.558^{* *}$ & $.606^{* *}$ \\
P & Sig. (2-tailed) & .000 & & .000 & .000 & .000 \\
& $\mathrm{~N}$ & 100 & 100 & 100 & 100 & 100 \\
& Pearson Correlation & $.510^{* *}$ & $.557^{* *}$ & 1 & $.559^{* *}$ & $.532^{* *}$ \\
& Sig. (2-tailed) & .000 & .000 & & .000 & .000 \\
& $\mathrm{~N}$ & 100 & 100 & 100 & 100 & 100 \\
& Pearson Correlation & $.550^{* *}$ & $.558^{* *}$ & $.559^{* *}$ & 1 & $.646^{* *}$ \\
& Sig. (2-tailed) & .000 & .000 & .000 & & .000 \\
& $\mathrm{~N}$ & 100 & 100 & 100 & 100 & 100 \\
& FS & $.576^{* *}$ & $.606^{* *}$ & $.532^{* *}$ & $.646^{* *}$ & 1 \\
& Pearson Correlation & .000 & .000 & .000 & .000 & 100 \\
\hline
\end{tabular}

Note. $* *$. Correlation is significant at the 0.01 level (2-tailed).

Purchase Intention (PI) has positive linear relationship with Value Perceived (VP), Price (P), Health Consciousness (HC) and Food Safety (FS). In addition, these correlations are statistically significant because Sig. $=0<0.05$. Among pairs of Purchase Intention (PI) each variable, the strongest Pearson correlation is between Food Safety (FS) and Purchase Intention (PI) with the value of coefficient $r$ of 0.646 . The second, third, fourth positions are Price (P) and Purchase Intention (PI), Value Perceived (VP) and Purchase Intention (PI), Health Consciousness (HC) and Purchase Intention (PI) with the value coefficient $r$ of $0.606,0.576$ and 0.532 respectively. All the value of coefficients $r$ are different from 0 , all variables would be retained to conduct Regression testing.

After Correlation had been finished, Multiple Linear Regression Analysis was conducted to predict value of dependent variable (Purchase Intention) based on independent variables (Value Perceived, Price, Health Consciousness and Food Safety).

Table 4. ANOVA ${ }^{\mathrm{a}}$

\begin{tabular}{lllllll}
\hline ANOVA $^{\mathrm{a}}$ & & & & & \\
\hline Model & & Sum of Squares & Df & Mean Square & $\mathrm{F}$ & Sig. \\
& Regression & 27.818 & 4 & 6.955 & 28.492 & $.000^{\mathrm{b}}$ \\
1 & Residual & 23.189 & 95 & .244 & & \\
& Total & 51.007 & 99 & & & \\
\hline
\end{tabular}

Notes. a. Dependent Variable: PI.

b. Predictors: (Constant), FS, VP, P, HC.

From the results presented in Table 4, Sig. value is lower than 0.05 (Sig. $=0)$ shows that this model is significant to predict dependent variable (Purchase Intention).

Table 5. Model Summary ${ }^{\mathrm{b}}$

Notes. a. Predictors: (Constant), FS, VP, P, HC.

\begin{tabular}{llllll}
\hline \multicolumn{2}{l}{ Model Summary } \\
\hline Model & R & R Square & Adjusted R Square & Std. Error of the Estimate & Durbin-Watson \\
\hline 1 & $.738^{\mathrm{a}}$ & .545 & .526 & .494 & 1.858 \\
\hline
\end{tabular}

b. Dependent Variable: PI.

From the Model Summary table, $\mathrm{R}$-squared $\left(\mathrm{R}^{2}\right)$ value is equal 0.545 or $54.5 \%$, it means the variance of independent variables (Value Perceived, Price, Health Consciousness and Food Safety) can explain 54.5\% the variance of dependent variable (Purchase Intention). The remaining $45.5 \%$ can be explained by other variables 
which do not exist in the research. R-squared in this research is $54.5 \%$ which is not too high but it is greater than $50 \%$, so it is good enough to fit this model. Furthermore, the significant coefficients can also represent the mean change in dependent variable when one unit of change in an independent variable while holding other independent variables in the model constant.

Table 6. Coefficients ${ }^{\mathrm{a}}$

\begin{tabular}{|c|c|c|c|c|c|c|c|c|}
\hline \multicolumn{9}{|c|}{ Coefficients $^{\mathrm{a}}$} \\
\hline \multirow[t]{2}{*}{ Model } & & \multicolumn{2}{|c|}{ Unstandardized Coefficients } & \multirow{2}{*}{$\begin{array}{l}\text { Standardized Coefficients } \\
\text { Beta }\end{array}$} & \multirow[t]{2}{*}{$\mathrm{t}$} & \multirow[t]{2}{*}{ Sig. } & \multicolumn{2}{|c|}{ Collinearity Statistics } \\
\hline & & $\mathrm{B}$ & Std. Error & & & & Tolerance & VIF \\
\hline \multirow{5}{*}{1} & (Constant) & -.030 & .352 & & -.086 & .931 & & \\
\hline & $\mathrm{VP}$ & .247 & .101 & .215 & 2.433 & .017 & .611 & 1.636 \\
\hline & $\mathrm{P}$ & .291 & .101 & .262 & 2.879 & .005 & .576 & 1.735 \\
\hline & $\mathrm{HC}$ & .087 & .088 & .091 & .993 & .323 & .573 & 1.745 \\
\hline & FS & .331 & .093 & .331 & 3.541 & .001 & .548 & 1.825 \\
\hline
\end{tabular}

Note. a. Dependent Variable: PI.

The Coefficients table gives important information to predict Purchase Intention based on Value Perceived (VP), Price (P), Health Consciousness (HC) and Food Safety (FS). Particularly, FS has highest Coefficients B of 0.331 indicated that Food Safety (FS) has strongest effect on Purchase Intention (PI). When FS increases by 1 unit, IT will increase by 0.331 units, on the contrary PI decreases by 0.331 units when FS decreases by 1 unit. On the other hand, Health Consciousness (HC) has lowest Coefficients B of 0.087 , besides at $5 \%$ level confidence Sig. value of $\mathrm{HC}$ is greater than 0.05 ( $\mathrm{Sig} .=0.323$ ), there is no evidence to prove Health Consciousness and Purchase Intention have statistically significant relationship. Finally, there only are Value Perceived, Price and Food Safety used in the regression equation.

Table 7. Hypothesis testing result

\begin{tabular}{|c|c|c|c|}
\hline Hypothesis & $\mathrm{B}$ & Sig. & Result \\
\hline $\begin{array}{l}\text { H1: There is a positive impact of Value Perceived on student's Purchase Intention of fast } \\
\text { food }\end{array}$ & 0.247 & 0.017 & Statistically significant \\
\hline H2: There is a positive impact of Price on student's Purchase Intention of fast food & 0.291 & 0.005 & Statistically significant \\
\hline $\begin{array}{l}\text { H3: There is a positive impact of Health Consciousness on student's Purchase Intention } \\
\text { of fast food }\end{array}$ & 0.087 & 0.323 & Not statistically significant \\
\hline $\begin{array}{l}\text { H4: There is a positive impact of Food Safety on student's Purchase Intention of fast } \\
\text { food }\end{array}$ & 0.331 & 0.001 & Statistically significant \\
\hline
\end{tabular}

The regression equation explailning the relationship between PI, VP, P and FS:

$$
P I=-0.03+0.247 V P+0.291 P+0.331 F S
$$

\subsection{Participant Flow}

\section{Respondents' information}

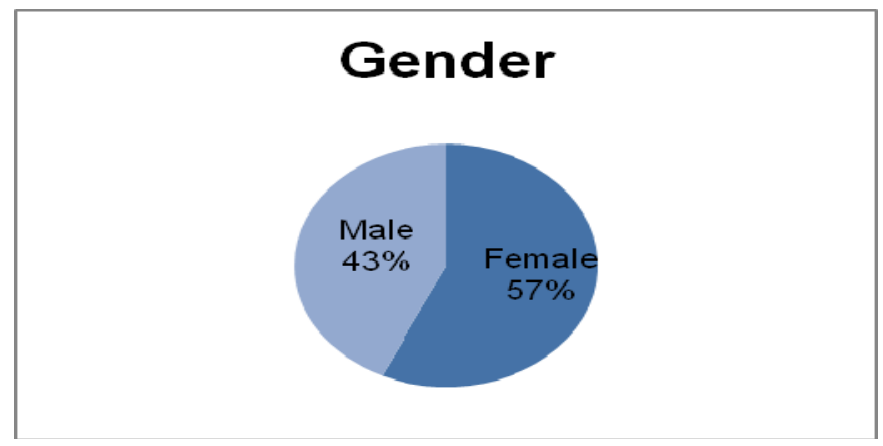

Figure 2. Percentage of respondents' gender 
Figure 2 shows that the percentage of female group of the sample is $57 \%$ which is larger than the one of male group with $43 \%$. The proportions of these two groups are nearly equal.

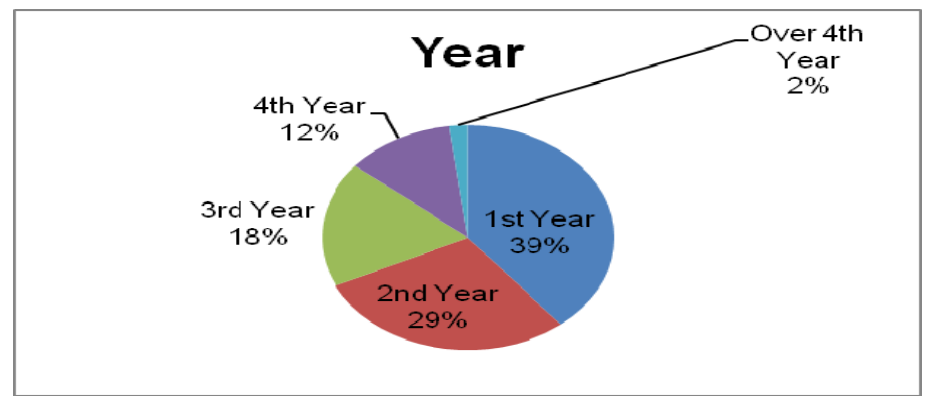

Figure 3. Percentage of respondents' years

Figure 3 shows the proportion of students in year groups. The first highest proportion is freshman group with $39 \%$, following that sophomore group is the second highest proportion with $29 \%$. While the third highest proportion of students is juniors with $18 \%$, senior get the fourth highest proportion with $12 \%$. In addition, there is $2 \%$ of over 4 th year students in this sample.

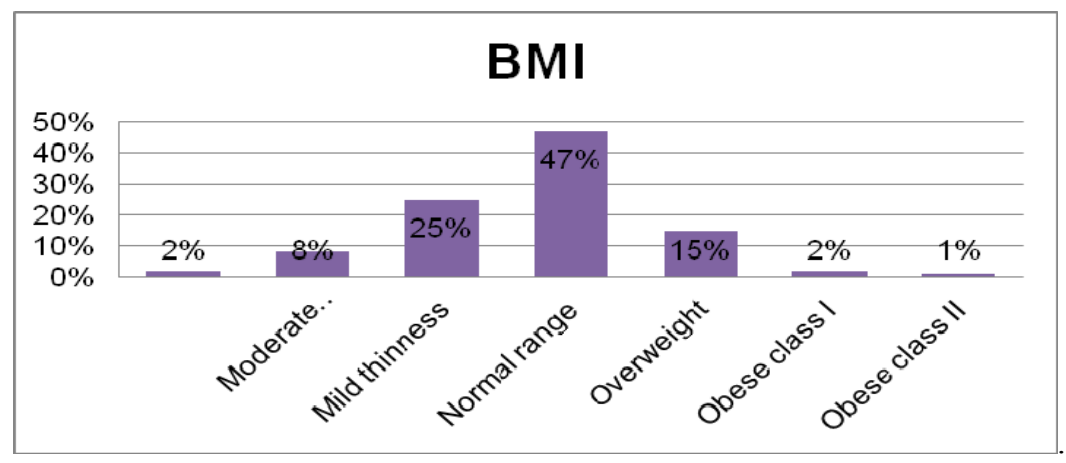

Figure 4. BMI of respondents

According to the bar chart above, while almost respondents are in normal range (47\%), mild thinness. Percentages of overweight, obese class I and obese II are $15 \%, 2 \%$ and $1 \%$ respectively. Likewise, those who are moderate thinness and severe thinness account for $8 \%$ and $2 \%$ of sample.

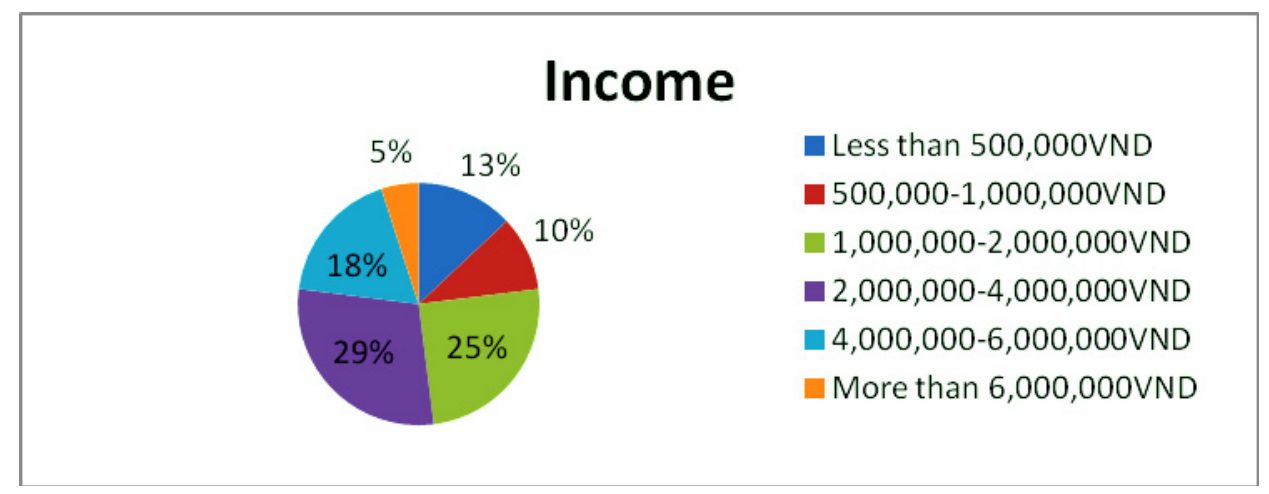

Figure 5. Respondents' monthly income 


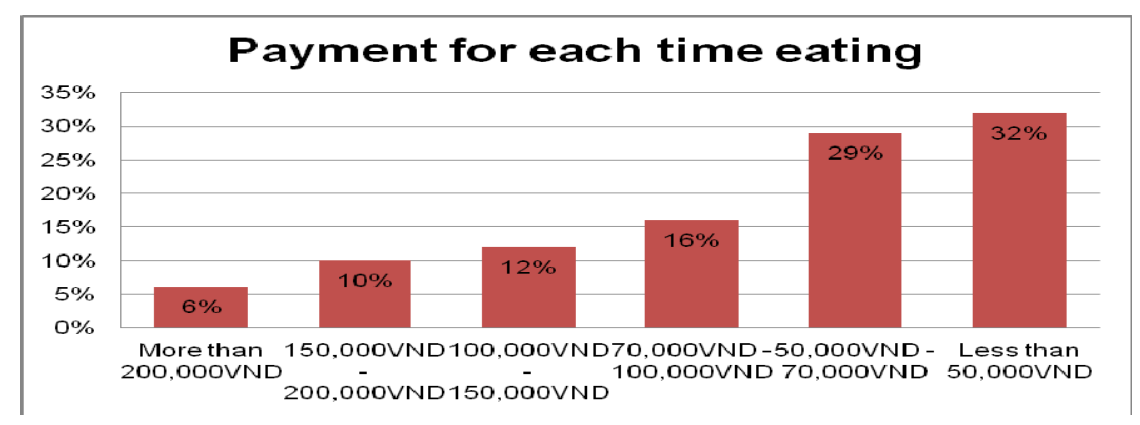

Figure 6. Respondents' payment for each time eating

Figure 6 illustrates the trend that the more money students have to pay for each time eating, the lower percentage of them have a meal with this price and vice versa. Likewise, there are $6 \%$ of respondents paying more than $200,000 \mathrm{VND}$ for each time eating, while those who pay less than 50,000VND contribute about $32 \%$ of sample.

\section{Respondents' fast food habit}

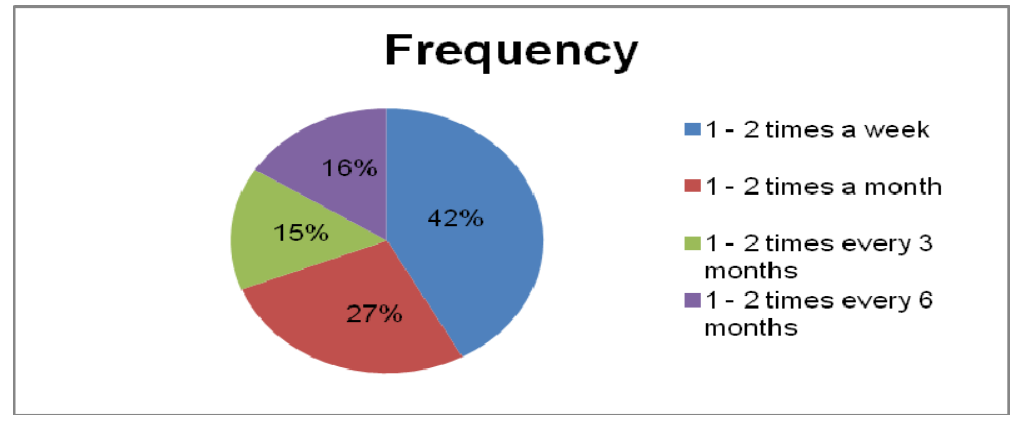

Figure 7. Respondents' consuming fast food frequency

According to the pie chart above, the percentage of respondents has fast food once or twice a week is $42 \%$, while this percentage decrease to $27 \%$ for those who having fast food once or twice a month. Moreover, the percentage of respondents has fast food once or twice every 3 months contribute $15 \%$ and $16 \%$ for those who having fast food once or twice every 6 months. This figure may indicate Binh Duong province will be a potential market for fast food business.

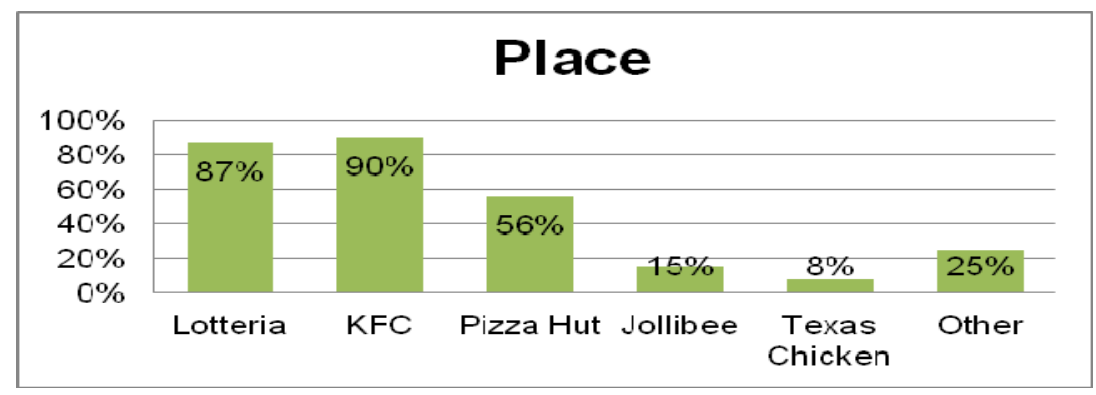

Figure 8. Fast food restaurant brand names

Most of students often have fast food at KFC restaurant chains with the highest percentage of $90 \%$, whereas the second most visited is Lotteria with second highest percentage of $87 \%$. The percentage of those who often visit Pizza Hut is about $56 \%$. The fourth and fifth most visited brand with $25 \%$ and $15 \%$ of respondents belongs to other and Jollibee, whereas the lowest percentage of those who visit Texas Chicken is only $8 \%$. In conclusion, KFC, Lotteria and Pizza Hut are the three most visited fast food brand of students. 


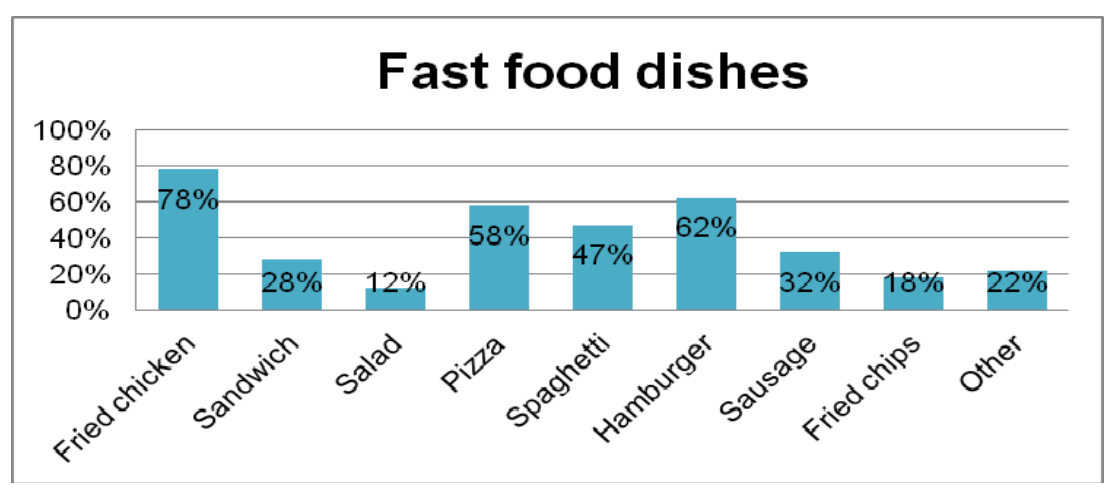

Figure 9. Fast food dishes

Figure 9 shows the four fast food dishes which they often have are Fried chicken with the proportion of $78 \%$, Hamburger (62\%), Pizza (58\%) and Spaghetti (47\%). It is easy to see that, Fried chicken is the most popular dish for fast food. Other dishes which respondents often have are Sausage (32\%), Sandwich (28\%), other (22\%), Fried chips (18\%) and Salad (12\%).

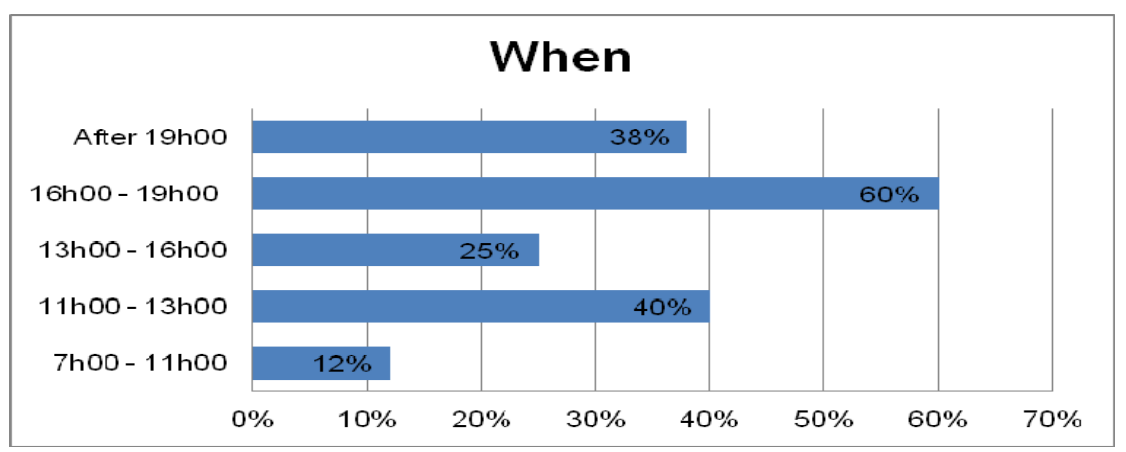

Figure 10. Time respondents often consume fast food

Figure 10 shows "What time do they often have fast food?" in which there are $60 \%$ of students often have fast food at $16.00 \mathrm{pm}-19.00 \mathrm{pm}$, as following that the percentage reduces to $40 \%$ at $11.00 \mathrm{am}-13.00 \mathrm{pm}$. Additionally, the percentage of respondents having fast food at other durations are $38 \%$ (after $19.00 \mathrm{pm}$ ), $25 \%$ $(13.00 \mathrm{pm}-16.00 \mathrm{pm})$ and $12 \%(7.00 \mathrm{am}-11.00 \mathrm{am})$. In short, most of respondents often have fast food after $16.00 \mathrm{pm}$.

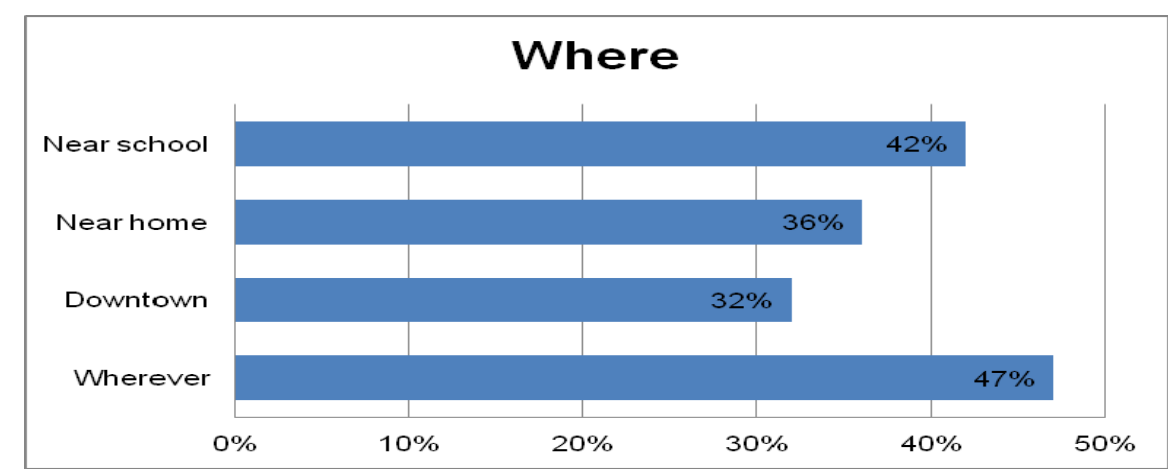

Figure 11. Place respondents often consume fast food

According to respondents' eating habit, this chart illustrates the location of restaurants that they often visit. There are around $47 \%$ of respondents answered "Wherever" when they were asked "Where do you often have fast 
food?". Moreover, the second position with $42 \%$ of students having fast food at restaurants is "Near school", while the third and fourth positions are "Near home" (36\%) and "Downtown" $(32 \%)$.

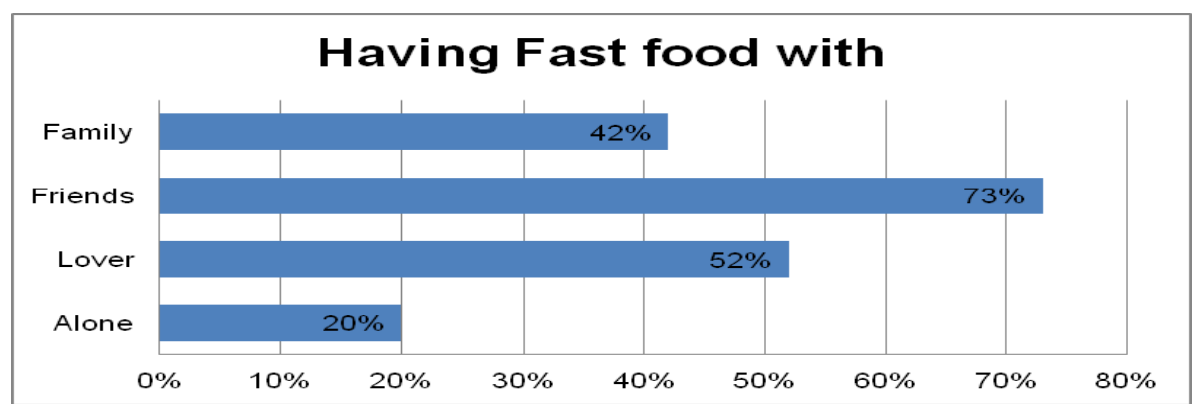

Figure 12. People respondents often consume fast food with

Figure 12 describes differences in the total amount of respondents have fast food with their friends was the most important factor, with $73 \%$ of respondents falling into one of the categories. It could be said that, fast food restaurant is a great environment to have a meeting with friends. The percentage of students who often have fast food with their lover and family contribute $52 \%$ and $42 \%$ of the sample respectively, while there is only $20 \%$ of respondents often have fast food alone.

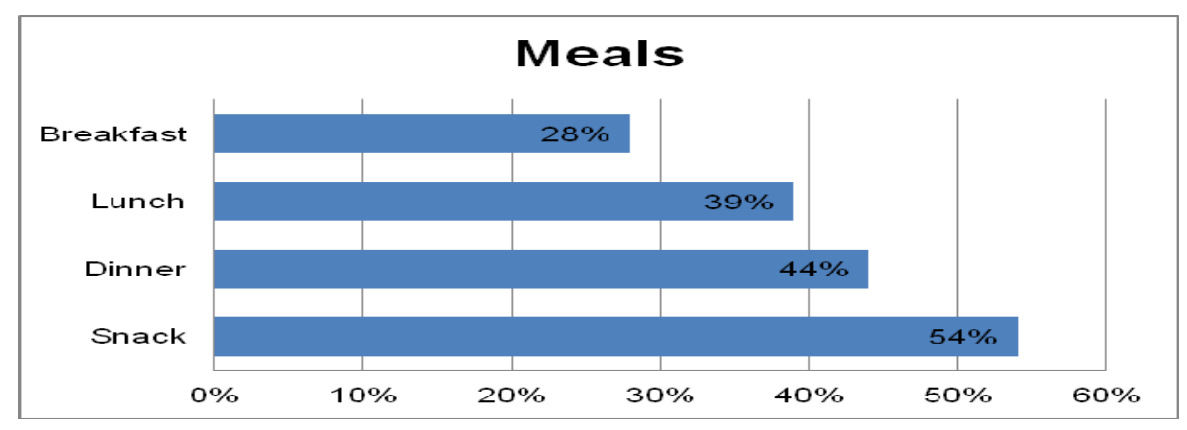

Figure 13. Meals respondents often consume fast food for

The Meals chart illustrates that whether respondents have fast food as a meal or snack. The highest percentage of respondent having fast food as a snack is $54 \%$, while they eat fast food for dinner with the proportion of $44 \%$. There is $39 \%$ of respondents have fast food for lunch whereas those who have fast food for breakfast just contribute $28 \%$ of the sample.

\section{Discussion}

From the academic findings, practical implication is also recommended, which might support the managerial decisions of fast food manufacturers in term of product development, marketing and communication. Our result showed that it is the essential for all fast food restaurants in Binh Duong province focusing on the level of food safety which is the first consideration of students' purchase intention through this study. In fact, food safety is also a fundamental principle to attract customers and build the reputation for any food restaurants. From the basic step like raw materials, input meat and vegetables to the methods of cooking related to food safety. Price and Value Perceived are the significant concerns of students when they make decision of buying fast food. As a result, the student group who has the limited income, so they should consider carefully to balance between their finance and eating habits. Accordingly, fast food restaurants should issue the price packages which are affordable and attract them as the first glance to get more consumers. Furthermore, the values which the consumers gain after paying that are also important such as the customers' services or money value whether it satisfies them or not.

Alongside the useful findings, several limitations of this pilot study need to be acknowledged. The first point is a concern regarding a narrow scope of students in Binh Duong province with small samples in which this research 
does not have ability to generalize the results in term of the whole country. It is recommended to have further studies in different cities and province with larger samples. Since then, more accurate insights of purchase habit of fast food would be draw out to represent for the Vietnamese market. Secondly, it just focuses on student group that not include other groups like children or professionals who are also very fond of fast food with different level of purchase intention. Last but not least, various stages of the consumers' buying decision have not been included in this research that also have critical impacts on the purchase intention of consumers, as following it is suggested that researchers should also consider and fulfill other determinants. In addition to the above implications, it is necessary for restaurants to collaborate with their consumers to review and get feedback in order to deeply understand the consumers continuously.

\section{References}

Anssi, T., \& Sanna, S. (2005). Subjective norm, attitudes and intentions of finish consumers in buying organic food. Bristish Food Journal, 808-822.

Baker, J., Grewal, D., \& Parasuraman, A. (1994). The influence of store environment on quality inferences and store image. Journal of the Academy of Marketing Science, 328-339. http://dx.doi.org/10.1177/0092070394224002

Becker, M. H., Maiman, L. A., Kirscht, J. P., Haefner, D. P., \& Drachman, R. H. (1977). The Health Belief Model and prediction of dietary compliance: a field experiment. Journal of Health \& Social Behavior, 18(4), 348-366. http://dx.doi.org/10.2307/2955344

Block, J. P., Scribner, R. A., \& DeSalvo, K. B. (2004). Fast food, race, ethnicity and income: A geographic analysis. American Journal of Preventive Medicine, 27(3), 211-217. http://dx.doi.org/10.1016/j.amepre.2004.06.007

Day, G. (1990). Market-Driven Strategy: Processes for Creating Value. New York: The Free Press.

Dickson, P. R., \& Sawyer, A. G. (1990). The Price Knowledge and Search of Supermarket Shoppers. Journal of Marketing, 42-53. http://dx.doi.org/10.2307/1251815

Etgar, M., \& Malhotra, N. K. (1981). Determinants of price dependency: Personal and perceptual factors. Journal of Consumer Research, 217-222. http://dx.doi.org/10.1086/208858

Gerald, W. L. (1985). The Lodging and Food Service Industry (p. 121). Educational Institute of the American Hotel \& Motel Association.

Grankvist, G., \& Biel, A. (2001). The importance of beliefs and purchase criteria in the choice of eco-labeled food products. Journal of Environmental Psychology, 21(4), 405-410. http://dx.doi.org/10.1006/jevp.2001.0234

Henson, S. (1996). Consumer willingness to pay for reductions in the risk of food poisoning in the UK. Journal of Agricultural Economics, 47, 403-420. http://dx.doi.org/10.1111/j.1477-9552.1996.tb00701.x

Huang, T. T., Harris, K. J., Lee, R. E., Nazir, N., Born, W., \& Kaur, H. (2003). Assessing overweight, obesity, diet and physical activity in college students. Journal of American College Health, 52(2), 83-86. http://dx.doi.org/10.1080/07448480309595728

Keller, K. L. (2001). Building customer based brand equity. Marketing Management, 10(2), 14-19.

Kraft, F. B., \& Goodell, P. W. (1993). Identifying the health conscious consumer. Journal of Health Care Marketing, 18-25.

Leszinski, R., \& Mam, M. V. (1997). Setting Value, Not Price. The Mckinsey Quarterly, 1, 99-115.

Jeffery, R. and S. A. French (1998). "Epidemic Obesity in the United States: Are Fast Foods and Television Viewing Contributing?" American Journal of Public Health 88(2): 277 280

Linda, J. V. (2014). Food safety. Retrieved from http://umm.edu/health/medical/ency/articles/food-safety

Monroe, K. (2003). Pricing: Making Profitable Decisions. Satisfaction: A Behavioral Perspective on the Consumer. New York, NY: Irwin/McGraw- Hill

Nagle, T. T., \& Holden, R. K. (2002). The Strategy and Tactics of Pricing: A Guide to Profitable Decision Making. New Jersey: Prentice-Hall.

Newsom, J. T., McFarland, B. H., Kaplan, M. S., Huguet, N., \& Zani, B. (2005). The health consciousness myth: implications of the near independence of major health behaviors in the North American population. Social Science \& Medicine, 60(2), 433-437. 
Padel, S., \& Foster, C. (2005). Exploring the gap between attitudes and behaviour: Understanding why consumers buy or do not buy organic food. British Food Journal, 606-625.

Parasuraman, A., Zeithaml, V.A. and Malhotra, A. (2005), "E-S-QUAL: a multiple-item scale for assessing electronic service quality",Journal of Service Research, Vol. 7 No. 3, pp. 213-33

Pereira, M. A., Kartashov, A. I., Ebbeling, C. B. L., Van Horn, M. L., Slattery, J., \& Ludwing, D. S. (2005). Fast food habits, weight gain and insulin resistance (the CARDIA study): 15 year prospective analysis. The Lancet, 365, 36-42. http://dx.doi.org/10.1016/S0140-6736(04)17663-0

Phuong, M. (2013). "Nóng" thị trường thức ăn nhanh. Retrieved from http:/thanhnien.vn/kinh-doanh/nong-thi-truong-thuc-an-nhanh-22157.html

Schiffman, L. G., \& Kanuk, L. L. (2000). Consumer Behavior. Wisconsin: Prentice Hall.

Schiffman, L., \& Kanuk, L. (2004). Consumer behavior. New Jersey: Prentice Hall.

Smith, M. F., \& Carsky, M. L. (1996). Grocery Shopping Behavior: A Comparison of Involved and Uninvolved Consumers. Journal of Retailing and Consumer Services, 73-80. http://dx.doi.org/10.1016/0969-6989(95)00048-8

Stamoulis, K. G., Pingali, P., \& Shetty, P. (2004). Emerging Challenges for Food and Nutrition Policy in Developing Countries. Ejade Electronic Journal of Agricultural \& Development Economics, 1(2), 154-167.

Thaler. (1985). The Influences of Perceived Value on Consumer Purchase Intention: The Moderating Effect of Advertising Endorser.

Thị trường fastfood: "Nội chiến" thương hiệu... ngoại! (n.d.). Chuyên mục Thị trường. Retrieved from http://www.brandsvietnam.com/1009-Thi-truong-fastfood-Noi-chien-thuong-hieungoai

Thị Trường Thức Ăn Nhanh: Cuộc chiến của những anh hào. (n.d.). Retrieved from http://www.tritri.org/thi-truong-thuc-an-nhanh-cuoc-chien-cua-nhung-anh-hao

Wallace, M. S., Yee, R., Yeung, M. W., \& Morris, J. (2005). Food safety: Building consumer trust in livestock farmers for potential purchase behaviour. British Food Journal, 841-854.

Warshaw, P. R., \& Fred, D. D.. (1985). Disentangling behavioral intention and behavioral expectation. Journal of Experimental Social Psychology, 21(3), 213-228. http://dx.doi.org/10.1016/0022-1031(85)90017-4

William, B. D., \& Monroe, K. B. (1985). The Effect of Brand and Price Information on Subjective Product Evaluations. Advances in Consumer Research, 12(3), 85-90.

Wilson, T. V. (n.d.). How Fast Food Works. Science. Retrieved from http://science.howstuffworks.com/innovation/edible-innovations/fast-food2.htm

Zeinab, S. S., \& Seyedeh, M. S. S. (2012). The main factors influencing purchase behavioural of organic products in Malaysia. Interdisciplinary Journal of Contemporary Research in Business, 98-116.

Zeithaml. (1988). Consumer perceptions of price, quality and value: A means-end model and synthesis of evidence. Journal of Marketing, 52(3), 2-22. http://dx.doi.org/10.2307/1251446

\section{Copyrights}

Copyright for this article is retained by the author(s), with first publication rights granted to the journal.

This is an open-access article distributed under the terms and conditions of the Creative Commons Attribution license (http://creativecommons.org/licenses/by/4.0/). 